\title{
Induktív és kombinatív gondolkodás fejlettségének online vizsgálata egyetemi tanulmányaikat kezdő hallgatók körében
}

A kutatás célja a Szegedi Tudományegyetemen tanulmányaikat kezdó hallgatók induktív és kombinatív gondolkodásának online

vizsgálata. Az adatfelvételben 1682 fó vett részt. Az induktív gondolkodás tesztben figurális sorozatok és analógiák, valamint

számsorozatok és számanalógiák szerepeltek. A kombinatív gondolkodást méró feladatotokban képekból, valamint betúkból

és számokból kellett különbözó összeállításokat megadni. Az adatfelvétel az eDia rendszer alkalmazásával valósult meg

az egyetem könyvtárának számitógépparkjában, a kitöltést mérési koordinátorok felügyelték. Bár a teszteken nyújtott átlagos teljesítmények nem voltak alacsonyak, a szórások és az eloszlások

vizsgálata, valamint az itemanalizis eredményei alapján feltételezhetó, hogy a teszteket kitöltó hallgatók negyede tanulási nehézségekkel nézhet szembe az egyetemi évei alatt.

\section{Bevezetés}

A tudásalapú társadalmak új igényeket fogalmaznak meg az oktatási rendszerekkel szemben, többek között azt az elvárást, hogy a népesség minél nagyobb aránya szerezzen felsőfokú képesítést (Európai Bizottság, 2010). Ennek megfelelően az utóbbi évtizedekben egyre többen vesznek részt felsőfokú képzésben, az expanzió azonban számos új kihívás elé állítja a felsőoktatási rendszereket (Csapó és Molnár, 2017a; Derényi és Temesi, 2016; Zlatkin-Troitschanskaia, Shavelson és Kuhn, 2015). Az egyik ilyen kihívás, hogy a társadalom egyre szélesebb rétegéinek felsőoktatásba lépésével a hallgatók tudásának és képességeinek szintje, valamint motivációjának mértéke is egyre szélesebb spektrumon szóródhat. Ez a jelenség kihat a hallgatók képezhetőségére, megfelelő intervenció híján a gyengébb képességü hallgatók diplomaszerzése elhúzódhat vagy lemorzsolódhatnak. Az eltömegesedett felsőoktatásban a jobb képességü hallgatók azonosítása is nehezebbé válik. A hatások összegződésével jelentősen romolhat a felsőfokú képzések eredményessége. Az új kihívásokra való hatékony reagálás minden szinten összetett feladat, legyen szó politikai, szakpolitikai, intézményi, kari, kurzus vagy az egyéni szintről, ugyanakkor a tervezéshez és a beavatkozások megvalósításhoz is nagymértékben hozzájárulhat, ha képet kapunk a tanulmányaikat megkezdő 
hallgatók általános gondolkodási képességeinek fejlettségéről. A növekvő hallgatói létszám miatt egy ilyen célú kutatás hagyományos, papír-ceruza tesztekkel való kivitelezése komoly anyagi és idői ráfordítást igényelhet (például nyomtatási, szervezési költségek, feladatok javítása, adatok feldolgozása). Az eredmények visszajuttatása az érintettek felé jelentősen elhúzódhat, így az adatok döntési folyamatokba való beépítése, általánosságban a mérések eredményeinek gyakorlati alkalmazhatósága is nehézkessé válhat. A technológiaalapú mérés-értékelési módszerek alkalmazása azonban nagymértékben elösegítheti a nagymintás mérések megvalósítását a tesztek kiközvetítésén át az eredmények visszacsatolásáig (Csapó, Ainley, Bennett, Latour és Law, 2012).

Jelen kutatás célja a Szegedi Tudományegyetemen tanulmányaikat kezdő hallgatók induktív és kombinatív gondolkodásának online vizsgálata. Az adatfelvétel egy nagyobb volumenü kutatás része volt, amely a felsőfokú tanulmányaikat megkezdő hallgatók különböző tudásterületeken nyújtott teljesítményének online felmérésére irányult (Molnár és Csapó, benyújtott kézirat). Az induktív és a kombinatív gondolkodás mellett a vizsgált konstruktumok között olvasás-szövegértés (Hódi és Tóth, 2019), matematikai gondolkodás, problémamegoldó képesség, tanulási stratégiák (Csapó és Molnár, 2017a; Molnár, 2019; Molnár és Csapó, benyújtott kézirat), valamint tanulási attitüdök és motívumok (D. Molnár és Gál, 2019) szerepeltek, továbbá az adatfelvétel része volt különböző háttérkérdések megválaszolása is. A következőkben csak az induktív és a kombinatív gondolkodásra irányuló vizsgálatokra fókuszálunk. Első lépésben a vizsgált konstruktumok elméleti háttere kerül bemutatásra, elsősorban annak alátámasztására, hogy az induktív és a kombinatív gondolkodás megfelelő képességeket jelentenek a hallgatók általános gondolkodási folyamatainak vizsgálatára, a tanulási potenciáljuk becslésére.

\section{Az induktív gondolkodás meghatározása}

Az induktív gondolkodás összetett konstruktum, számos megközelítés létezik a leírására és vizsgálatára (Pásztor, 2016). Klauer az összehasonlítási folyamatokat tekinti az induktív gondolkodás egyik lényeges

Az induktív gondolkodás összetett konstruktum, számos megközelítés létezik a leirására és vizsgálatára (Pásztor, 2016).

Klauer az összehasonlítási folyamatokat tekinti az induktív gondolkodás egyik lényeges jellemzójének: folyamat során elsó lépésben azonosítjuk a valóság elemeinek tulajdonságait, valamint az egyes elemek közötti összefüggéseket, ezt követôen hasonlóságokat és különbözôségeket állapítunk meg, melyek révén szabályokat ismerünk fel (Klauer, 1997, 1999). A megfigyelt esetek elemzése során azonositott szabályok alapján képesek vagyunk általánosításokat, predikciókat

megfogalmazni a meg nem figyelt esetekre is, ezen lépésben induktív következtetéseket végzünk. Klauer tehát elkülöníti egymástól az induktiv gondolkodás összehasonlitó, elemzó, valamint következtetó

mechanizmusait (Klauer és Phye, 2008). Az elóbbi vizsgálata fóként az általános intelligencia pszichometrikus, míg az utóbbi a kognitív pszichológiai kutatási tradíciókhoz köthetó (lásd például Carroll, 1993; Hayes, Heit és Swendsen, 2010). 
jellemzőjének: folyamat során első lépésben azonosítjuk a valóság elemeinek tulajdonságait, valamint az egyes elemek közötti összefüggéseket, ezt követően hasonlóságokat és különbözőségeket állapítunk meg, melyek révén szabályokat ismerünk fel (Klauer, 1997, 1999). A megfigyelt esetek elemzése során azonosított szabályok alapján képesek vagyunk általánosításokat, predikciókat megfogalmazni a meg nem figyelt esetekre is, ezen lépésben induktív következtetéseket végzünk. Klauer tehát elkülöníti egymástól az induktív gondolkodás összehasonlító, elemző, valamint következtető mechanizmusait (Klauer és Phye, 2008). Az előbbi vizsgálata főként az általános intelligencia pszichometrikus, míg az utóbbi a kognitív pszichológiai kutatási tradíciókhoz köthető (lásd például Carroll, 1993; Hayes, Heit és Swendsen, 2010). A terület különböző megközelítései ugyanakkor mind egyetértenek abban, hogy az induktív gondolkodás, következtetés kiemelt szerepet játszik a megismerési folyamatokban. Az új tudás megszerzésének eszközeként, a tanulási potenciál indikátoraként is említik, a képességnek fontos szerepet tulajdonítanak a tudás transzferálhatóságában is (Csapó, 1998; Resing, 1993). Az általános intelligenciára, az értelem szerkezetének feltárására irányuló kutatások a fluid intelligencia - a gondolkodás különböző műveletvégzési folyamatai - hatékonyságának egyik meghatározó faktoraként tartják számon (Carroll, 1993; Demetriou, Spanoudis és Mouyi, 2011).

Ebben a kutatási tradícióban jellemzően alkalmazott feladattípusnak tekinthető a különböző tartalommal megszerkesztett sorozatok folytatása, analógiák megoldása, osztályozás vagy mátrix feladatok. Az induktív gondolkodás jelentőségére utal, hogy számos más gondolkodási képesség viszonylatában emelik ki a szerepét, vagy találnak összefüggéseket, kapcsolatokat, úgy mint az analógiás, az arányossági, vagy a deduktív gondolkodás, a problémamegoldás vagy a természettudományos gondolkodás (Csapó, 1998; B. Németh, 1998; Dunbar és Fugelsang, 2005; Johnson-Laird, 2006; Molnár, Greiff és Csapó, 2013; Nagy Lászlóné, 2006; Simon és Lea, 1974).

\section{A kombinatív gondolkodás meghatározása}

A kombinatív gondolkodás szintén az egyik alapvető gondolkodási mechanizmusaink egyike, amely számos hétköznapi helyzetben, összetett problémák megoldásában vagy tudományos tevékenységben megjelenhet. A kominatív gondolkodás során elöre megadott, vagy a rendelkezésre álló elemekből kell összeállítanunk bizonyos feltételeket kielégítő, különböző konstrukciókat (Csapó, 2001a). A terület vizsgálata a modern pszichológiában is hosszú időre nyúlik vissza, a kombinatív gondolkodás többek között kiemelkedő szerepet töltött be Piaget a gondolkodás általános fejlődésének leírására irányuló elméletében (Inhelder és Piaget, 1967; Csapó, 1988). A gondolkodás műveleti szakaszainak elemzéséhez Piaget gyakran használt olyan feladatokat, amelyek a résztvevőktől a különböző elemek feltételek szerinti felsorolását várta el, például három adott szín esetén az összes lehetséges háromszínű zászló létrehozását vagy bonyolult vizsgálati helyzeteket, melyekben a vizsgálati személyeknek meg kellett adni négy színtelen folyadék összes lehetséges vegyítését annak érdekében, hogy az indikátor meghatározott színüre változzon (Inhelder és Piaget, 1967). A példák is világosan rámutatnak, hogy a kombinatív gondolkodásnak kiemelt szerepe van a természettudományos gondolkodásban vagy a problémamegoldásban (Adey és Csapó, 2012; Poddiakov, 2011; Wu és Molnár, 2018). Egy kísérlet megvalósításakor például gyakori helyzet, hogy elöre megtervezzük a változók lehetséges kombinációit, egy probléma megoldásakor fontos szempont, hogy mérlegeljük a kiindulási helyzet elemeinek minél több lehetséges változatát, szisztematikusan elemezzük a változók lehetséges érték-kombinációit. A kombinatív gondolkodás továbbá összefüggésbe hozható a kreativitás, az intuíció világával is, számos kutató érvel amellett, hogy a kombinatív képesség megfelelő szintủ fejlettsége segíti 
a divergens, vagy más néven széttartó gondolkodás folyamatait, az egyes elemek sokféle összeállításának képessége hozzájárulhat a fantázia müködéséhez (Csapó és Pásztor, 2015; Simonton, 2010; Fishbein és Grosman, 1997).

Az induktív és a kombinatív gondolkodás tehát megfelelő indikátorai lehetnek az általános értelmi képességeknek, a két konstruktum együttes vizsgálata hatékony alapot jelenthet a hallgatók tanulási potenciáljának elemzéséhez.

\section{Induktív és kombinatív gondolkodás vizsgálata}

A kutatás célja az egyetemi tanulmányaikat kezdő hallgatók induktív és kombinatív gondolkodásának a vizsgálata online tesztekkel. A kutatási kérdések egy része a méröeszközök beválására, míg a másik része a hallgatók teljesítményének elemzésére irányul. Egyrészről megvizsgáljuk, hogy az online feladatsoraink megfelelő pszichometriai jellemzőkkel rendelkeznek-e, alkalmasak-e a megcélzott konstruktumok mérésére, összességében megfelelö módszernek bizonyul-e az online tesztelés a célok megvalósításához. Ezt követően arra keressük a választ, hogy vajon a minta eredményeinek elemzésével, valamint részletesebb itemanalízísek segítségével megbecsülhető-e azon hallgatók aránya, akik tanulási nehézségekkel nézhetnek szembe egyetemi éveik során.

\section{Minta}

A kutatás célcsoportját a Szegedi Tudományegyetemen tanulmányaikat megkezdő nappali tagozatos hallgatók jelentették, összesen 3873 fö. A vizsgálatban való részvétel önkéntes volt, a hallgatók előzetesen értesítést kaptak a tesztek kitöltésének lehetőségéről, a feladatsorok megoldásáért kreditpontokat szerezhettek. A teljes egyetemi bemeneti mérésben 1682 fó vett részt, ami 43\%-os részvételi aránynak felel meg. Az induktív gondolkodás és a kombinatív képesség teszteket 1355 hallgató oldotta meg, ami 35\%-os részvételi arányt jelent. A minta átlagéletkora 19,8 év (szórás $=2,1$ év), a nők aránya 49,1\% volt. A hallgatók 66\%-a 2017-ben, 13\%-a 2016-ban, 7\%-a 2015-ben, 5\%-a 2014-ben, 3\%-a 2013-ban, $2 \%$-a 2012-ben tett érettségit. 2012 előtt a hallgatók 4\%-a érettségizett, a legkorábban 2001-ben. Az egyetem karainak részvételi aránya $22-69 \%$ között mozgott.

\section{Mérőeszközök, eljárások}

\section{Méröeszközök}

A 38 itemet tartalmazó induktív gondolkodás tesztben 8 figurális sorozat, 8 figurális analógia, valamint 11 számsorozat és 11 számanalógia szerepelt (1. ábra). A feladatokat az SZTE Oktatáselméleti Kutatócsoport és az MTA-SZTE Képességfejlődés Kutatócsoport fejlesztette (Csapó, 1998, 2001b; Pásztor, 2016; Pásztor, Molnár, B. Németh, Korom és Csapó, 2017). A figurális sorok és analógiák, valamint a számanalógiák esetében öt válaszlehetőség közül kellett a helyes megoldást kiválasztani, amely egy pontot ért. A számsor esetében hét válaszlehetőségből kettő elem kiválasztásával kellett folytatni a megadott sorozatot. Pontot csak akkor ért a feladat, ha mindkét válasz helyes volt.

A kombinatív gondolkodás teszt 8 feladatból állt, három esetben képekből, öt feladatban pedig betükböl és számokból kellett különbözö összeállításokat megadni. A teszt Csapó (1988, 2001a) feladatainak online adaptációját jelentette (Csapó és Pásztor, 2015; 2. ábra). Az adatfelvétel idői keretei miatt az eredeti, rövidített tesztváltozat 12 
feladatából nyolc került be a mérésbe, melyek a következő műveletek végzését követelték meg a hallgatóktól: ismétlés nélküli variációk és kombinációk, ismétléses variációk, valamint összes részhalmaz képzése (lásd: Csapó, 2001a). A feladatok értékelése a már korábban több vizsgálatban alkalmazott J index használatával történt (Csapó, 1988; Csapó, 2001a). A J index az összes lehetséges jó, a kitöltő által adott helyes, valamint a hibás és a redundáns konstrukciók számának figyelembevételével minden feladat megoldásához egy 0 és 1 közötti értéket rendel, ahol az 1-es érték az összes helyes konstrukció megadását jelenti hibás és redundáns válasz nélkül. Ezáltal, bár a teszt csak nyolc feladatból állt, az értékelés felbontása lényegesen finomabb.

Folytasd a sort!

Melyik kép illik leginkább a sárga keretbe?

Húzd oda!
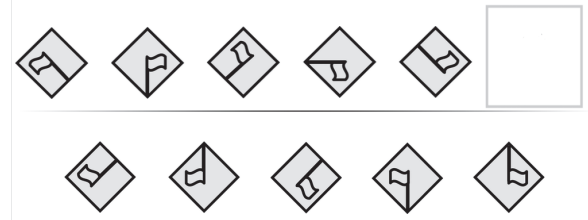

- Vissza

a)

Folytasd a sorozatot! Húzd azokat a számokat a sárga keretekbe, melyek

a legjobban odaillenek a számsor folytatásaként!

\begin{tabular}{|l|l|l|l|l|l|}
\hline 1 & 10 & 26 & 51 & 87 & 136 \\
\hline
\end{tabular}

$\begin{array}{lllllll}145 & 161 & 146 & 162 & 151 & 200 & 281\end{array}$

c)

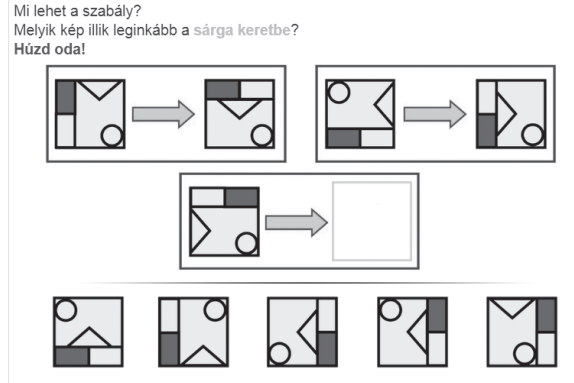

- Vissza

Tovabb :

b)

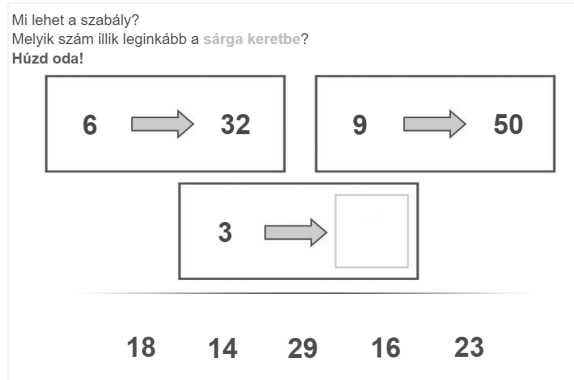

- Vissza

Tovább 。

d)

1. ábra. Példafeladatok az induktív gondolkodást mérö feladatsorból: a) figurális sorozat, b) figurális analógia, c) számsorozat, d) számanalógia 
Ebben a feladatban minden jelet csak egyszer hasznáthatsz fel, vagyis egy-egy jelsorozatnak csupa különbözö jelböl kell állni.

Allítsd elő az ábrán látható öt jelbốl az összes különbözö, KËT JELBÖL álló jelsorozatot. Vigyázz! Több hely van, mint amennyi különbözzó lehetöség!

\section{$\circ \square \Delta+-$}

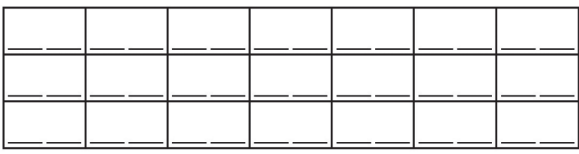

- Vissza

a)

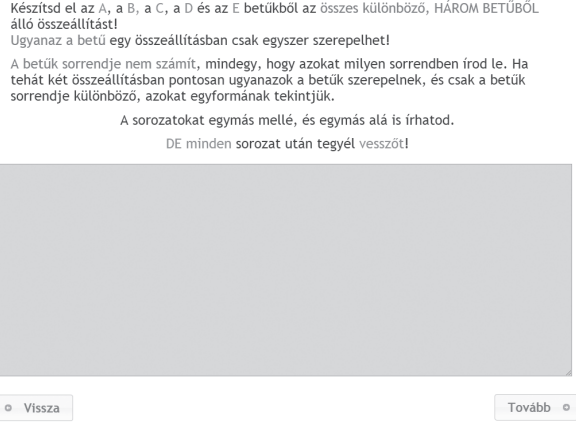

b)

2. ábra. Példafeladatok a kombinatív gondolkodást mérö feladatsorból:

a) ismétlés nélküli variáció - figurális, b) ismétlés nélküli variáció - formális

\section{Eljárások}

A tesztek kitöltése 2017 szeptemberében az egyetem könyvtárának számítógépparkjában zajlott, amely egyidejüleg összesen 150 fö befogadását tette lehetővé. Az adatfelvétel az eDia rendszer alkalmazásával valósult meg (Molnár, Makay és Ancsin, 2018; Csapó és Molnár, 2017b). Az adatfelvétel objektivitásának biztosítása érdekében a mérések lebonyolítását mérési koordinátorok felügyelték, akik kizárólag technikai segítséget nyújtottak a hallgatóknak. A résztvevők az egyetemi rendszerben (Neptun) feljelentkezett időpontban csoportokban érkeztek, a leültetést, a rendszerbe való belépést, és a személyazonosság ellenőrzését szintén a mérési koordinátorok végezték. A rendszerbe való belépéshez a hallgatók elöre kinyomtatott instrukciókat is találhattak az asztalokon.

A hallgatók a két tesztet közvetlenül egymást követöen oldották meg, majd egy rövid kérdőívet is kitöltöttek, erre összesen 60 perc állt rendelkezésükre. A feladatok kiértékelését az eDia rendszer automatikusan elvégezte, a tesztkitöltést követően a százalékos eredmény azonnal megjelent a képernyőn. Az adatfelvétel lezárta után a hallgatók további személyre szabott visszajelentést is kaptak (Molnár és Csapó, benyújtott kézirat). Az egyéni visszajelentés tartalmazta a felmerés rövid bemutatását, a tesztek leírását, magyarázatot az egyéni visszajelentés értelmezéséhez, az adott hallgató egyes teszteken, illetve azok résztesztjein nyújtott eredményét a többi hallgató teljesítényének viszonylatában, továbbá fejlesztési javaslatokat is. Az adott hallgató erősségeinek és fejlesztendő területeinek azonosítását a számszerü értékek mellett pókhálóábrák is segítették (3. ábra). A 3. ábrán látható számok az egyes tudásterületeket reprezentálták, a piros vonal a hallgató teljesítményét mutatta. A kék vonal a hallgató karának átlagos teljesítményét, míg a zöld vonal az egyetemi szintü átlagos eredményeket jelzi, ezáltal a hallgatók két viszonyítási értékkel is összevethették saját teljesítményüket. 


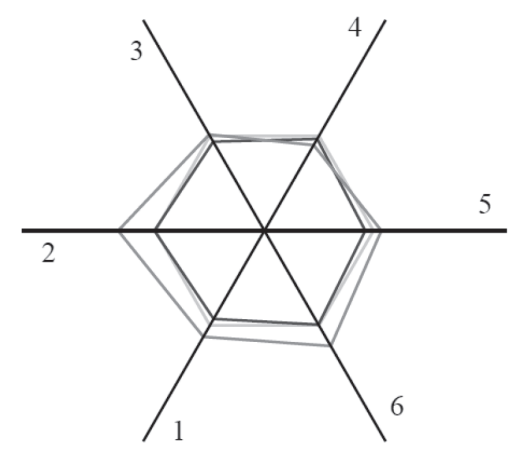

3. ábra. A hallgatóknak készült egyéni visszajelentésekben megjelenö pókhálóábra. A számok a különbözö tudásterületeket jelzik: 1. matematikai gondolkodás, 2. olvasás-szövegértés, 3. problémamegoldó képesség, 4. vizuális emlékezet, 5. induktív gondolkodás, 6. kombinatív gondolkodás. Piros vonal: hallgató teljesitménye, kék vonal: átlagos kari, zöld vonal átlagos egyetemi teljesítmény

(forrás: Molnár és Csapó, benyújtott kézirat)

\section{Eredmények}

A mérőeszközök megbízhatósága megfelelőnek bizonyult, a teljes tesztek szintjén a Cronbach-alfa mutatók értéke jónak minősíthető (1. ábra). A figurális induktív feladatokat tartalmazó részteszt megbízhatósága alacsony, de nem olyan mértékben, hogy szükséges volna a további elemzésekből elhagyni. A két teszten elért teljesítmények közepesen erös pozitív összefüggést mutattak, $\mathrm{r}=0,45(\mathrm{p}<0,01)$. A tesztek átlagos megoldottsága alapján megállapítható, hogy a hallgatók nagyobb részének nem okoztak nehézséget a feladatok, a legalacsonyabb szinten megoldott részteszt átlaga is $59,6 \%$ pont (1. ábra). Az induktív gondolkodás esetében jól elkülönül a figurális és a számfeladatok nehézsége közötti különbség, a figurális feladatok szignifikánsan könnyebbek voltak; $\mathrm{t}(1354)=35,46 \mathrm{p}<0,01)$.

1. táblázat. Az induktív és a kombinatív gondolkodás tesztek pszichometriai jellemzői

\begin{tabular}{|c|c|c|c|}
\hline Teszt & Feladatok száma & Cronbach- $\alpha$ & Átlag (szórás) \% \\
\hline Teljes induktív teszt & 38 & 0,84 & $66,5(16,2)$ \\
\hline $\begin{array}{c}\text { Figurális } \\
\text { feladatok }\end{array}$ & 16 & 0,68 & $76,0(16,9)$ \\
\hline Számfeladatok & 22 & 0,80 & $59,6(19,1)$ \\
\hline Kombinatív teszt & 8 & 0,79 & $69,3(21,9)$ \\
\hline
\end{tabular}

Minden teszt esetében megfigyelhető a szórás magas értéke, amelyek az egyéni teljesítmények közötti nagy különbségeket jelzi. Ez különösen az induktív számfeladatoknál és a kombinatív feladatoknál figyelhető meg. A teljesítmények eloszlását mutató 4. és 5. ábrák mélyebb betekintést engednek a hallgatók teljesítményében jelentkező egyéni különbségekbe. A magas átlagos teljesítmény visszatükröződik a jobbra dőlő eloszlásokban, a kombinatív gondolkodás feladatok esetében jól látszik, hogy a magasabb képességszinteken a teszt már nem rendelkezett megfelelő differenciáló erővel. Ugyanakkor az is látható, hogy a hallgatók egy jelentős arányának nehézséget okoztak a feladatok. Az induktív gondolkodás teszt vonatkozásában a kitöltők 31\%-a 60\%pont, 14\%-a 50\%pont 
alatt teljesített. A kombinatív gondolkodás feladatsornál ezek az arányok a következőképpen alakultak: $25 \%$ és $15 \%$.
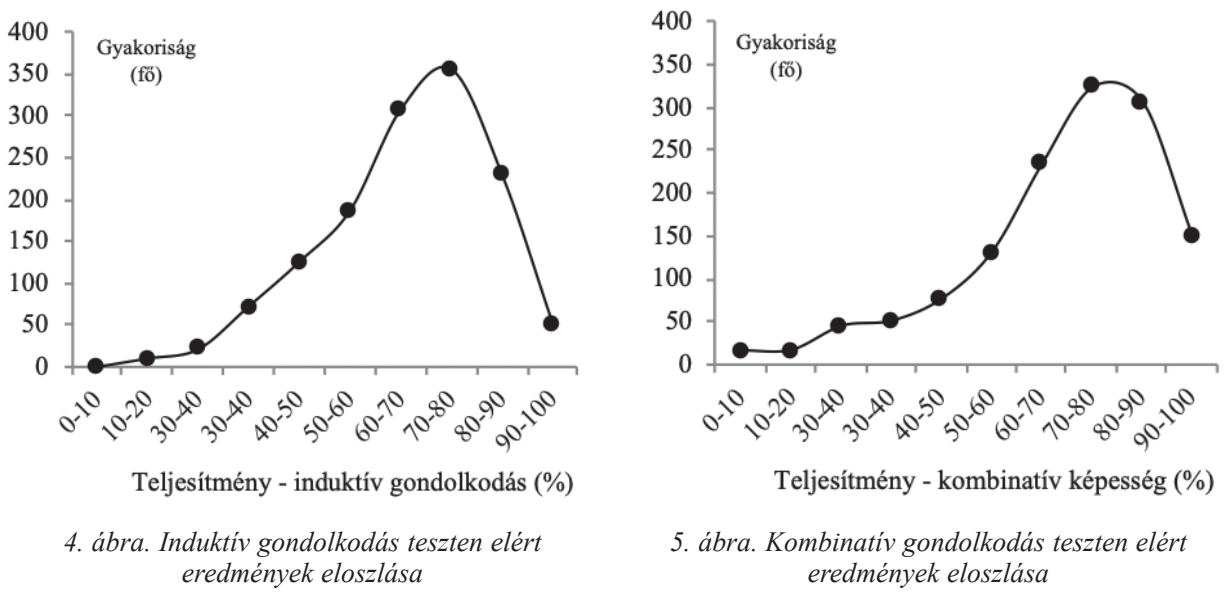

A hallgatók tudásának minőségéről további információkat nyerhetünk, ha megvizsgáljuk néhány tipikus feladat megoldottságát, ezáltal árnyaltabb képet kaphatunk arról, hogy mik azok a tudáselemek, gondolkodási müveletek, amelyek alkalmazása nem okozott problémát, vagy épp ellenkezőleg, nehézséget jelentett a hallgatók számára. A módszertani részben bemutatásra került hat példafeladat, a 2. táblázat az induktív gondolkodás feladatokat helyesen megoldók arányát foglalja össze. A figurális sorozatban azt a szabályt kellett felismerni, miszerint a zászló minden lépés során tesz egy nyolcad fordulatot a négyszögön belül, valamint a zászló iránya is ellentétesre vált. A feladatban tehát két jellemzőt, vagy ha úgy tetszik, két változót és annak lehetséges értékeit kellett azonosítani, és a változásban rejlő szabályt felismerni. Az adatok alapján ez a feladat hozzávetőlegesen tízből három hallagatónak nehézséget jelentett. A figurális analógiában már négy változó jelenik meg: a négyzeten belüli hosszú téglalap helyzete (negyed fordulatot tesz) és színezése (ellentétesre vált), a háromszög helyzete („ráül” a hosszú téglalapra), valamint a kör helyzete (megörzi szemben álló helyzetét a hosszú téglalappal, és követi annak eredeti színezését). A 2. táblázat alapján tízből négy főnek ezen négyváltozós szabály felismerése és alkalmazása nem sikerült. A számsorozatban az első számhoz a hármas szám második hatványát kell hozzáadni, majd ezt követően a második számhoz a négy második hatványát, majd a harmadik számhoz az öt második hatványát, és így tovább. A számanalógia esetében, ha a kiindulási számot x-szel, a nyíl jobb oldalán álló számot pedig $\mathrm{y}$-nal jelöljük, akkor a feladat az y=6x-4 függvény felismerését és alkalmazását várta el a hallgatóktól. Az eredményeink alapján mindkét feladat vonatkozásában hozzávetőlegesen a hallgatók fele adott helyes megoldásokat. 
2. táblázat. A módszertani fejezet, Méröeszközök alfejezetben bemutatott induktív gondolkodást mérö feladatok megoldottsága

\begin{tabular}{|l|c|}
\hline \multicolumn{1}{|c|}{ Feladat } & $\begin{array}{c}\text { A feladatot helyesen megoldók } \\
\text { aránya (\%) }\end{array}$ \\
\hline Induktív, figurális sorozat (1. ábra, a) & 66,7 \\
\hline Induktív, figurális analógia (1. ábra, b) & 59,7 \\
\hline Induktív, számsorozat (1. ábra, c) & 51,1 \\
\hline Induktív, számanalógia (1. ábra, d) & 53,4 \\
\hline
\end{tabular}

A kombinatív gondolkodás feladatok megoldottságát a 3. táblázat foglalja össze. A figurális feladatban (2. ábra, a) öt jel felhasználásával kellett két jelből álló jelsorozatokat összeállítani úgy, hogy egy-egy jelsorozatnak különböző jelekből kellett állnia (összesen 20 ilyen jelsorozat készíthető). A feladatok kiértékelésére használt $\mathrm{J}$ indexek átlaga $68,3 \%$ pont volt, ami közel van a teljes teszt átlagos megoldottságához, tehát ez egy átlagos nehézségü feladatnak tekinthető (lásd: 1 . és 3. táblázat).

3. táblázat. A módszertani fejezet, Méröeszközök alfejezetben bemutatott kombinatív gondolkodást mérö feladatok megoldottsága

\begin{tabular}{|l|c|c|c|c|}
\hline \multicolumn{1}{|c|}{ Feladat } & $\begin{array}{c}\text { J index átlag } \\
\mathbf{( \% )}\end{array}$ & $\begin{array}{c}\mathbf{J} \text { index } \geq \mathbf{0 , 9} \\
\text { (hallgatói } \\
\text { arány, \%) }\end{array}$ & $\begin{array}{c}\text { J index } \mathbf{0 , 3} \\
\text { (hallgatói } \\
\text { arány, \%) }\end{array}$ & $\begin{array}{c}\text { J index } \\
\text { (hallgatói } \\
\text { arány, \%) }\end{array}$ \\
\hline $\begin{array}{l}\text { Kominatív, figurális } \\
\text { (2. ábra, a) }\end{array}$ & 68,3 & 41,1 & 5,6 & 2,4 \\
\hline $\begin{array}{l}\text { Kominatív, formális } \\
\text { (2. ábra, b) }\end{array}$ & 53,5 & 24,9 & 28,6 & 24,5 \\
\hline
\end{tabular}

Megjegyzés: A „J index átlag (\%)” a feladatra kapott J indexek átlagát jelenti, míg a „hallgatói arány, \%” kifejezés az adott $\mathrm{J}$ index értéket elérő hallgatók arányát mutatja.

A J index egy 0 és 1 közötti érték, ahol az egyes érték a hibátlan megoldást jelenti, ezért a feladat megoldottságáról többet elárul, ha megvizsgáljuk, hogy a hallgatók mekkora aránya ért el 0,9 vagy a fölötti értéket. Ez az arány $41,1 \%$, tehát átlagosan a tízből négy hallgató tudta alapvetően helyesen megoldani a feladatot. A résztvevők 38\%-ának a teljesítménye 0,5 körüli J indexszel jellemezhető, 5,6\%-a a 0,3 tizedes $\mathrm{J}$ index értéket sem érte el. A teljesen helytelen megoldást adók aránya $2,4 \%$ volt, az ő esetükben a $\mathrm{J}$ index $=0$ (3. táblázat). A formális feladat (2. ábra, b) valamivel nehezebbnek bizonyult, az átlagos J index 53,5\%pont. A feladatban öt betüt felhasználva kellett megtalálni az összes különböző, három betüből álló összeállítást úgy, hogy ugyanaz a betü egy összeállításban csak egyszer szerepelhet, és a betűk sorrendje sem számított (10 ilyen betűsor állítható össze). A feladat további nehézsége a figurálissal szemben, hogy itt nem áll rendelkezésre egy elöre összeállított keret, ami strukturálná az összeállításokat, a kitöltés során a betüsorokat vesszővel elválasztva kellett begépelni. A 0,9 feletti J indexszel rendelkezők aránya itt már lényegesen alacsonyabb, a résztvevők 24,9\%-a esik ebbe a halmazba. Jelentősen megnőtt a 0,3 alatti J indexet elérők száma is: $28,6 \%$. A teljesen helytelen megoldást adók $(\mathrm{J}$ index $=0)$ aránya is igen magas, a hallgatók 24,5\%-a tartozik ebbe a kategóriába (3. táblázat). 


\section{Összefoglalás, következtetések}

A kutatás célja az egyetemi tanulmányaikat megkezdő hallgatók induktív és kombinatív gondolkodásának online vizsgálata volt. Az eredmények alapján a tesztek megbízhatósága megfelelőnek bizonyult, bár az elkövetkező kutatásokban a figurális induktív feladatok részteszt továbbfejlesztésre szorul. Továbbá az átlagos teljesítmények és az eloszlások megmutatták, hogy a jövőben érdemes a magasabb képességszintek differenciálására további feladatokat fejleszteni. Az induktív és kombinatív gondolkodás közötti együttjárás jelzi a képességek közötti szoros összefüggést, azonban a korreláció mértéke egyértelmüen rámutat arra is, hogy a két teszt a gondolkodás különböző területeiről szolgáltathat információt, ezért érdemes mindkét képességet a vizsgálat tárgyává tenni.

Bár a teszteken nyújtott átlagos teljesítmények nem voltak alacsonyak, a szórások és az eloszlások vizsgálata, valamint az itemanalízis eredményei is arra utaltak, hogy a hallgatók egy jelentős arányának tanulási nehézségei adódhatnak a tanulmányaik során. Az eddigi adatok tükrében nehéz lenne pontos becslést adni erre az arányra. Az egyes feladatok követelményeinek az elemzése képet adott arról, hogy mely tudáselemek, müveletek elvégzése az, amely problémát jelentett a hallgatóknak. További empirikus adatok hiányában csak feltételezések fogalmazhatók meg azzal kapcsolatban, hogy milyen mértékben problematikus egy egyetemi hallgató tanulmányainak eredményességére nézve, ha nehézséget jelent számára a figurális mintázatokban két jellemző változásában rejlö szabályszerüség felismerése, egy négyzetszámokkal növekvő sorozat folytatása, vagy öt elem felhasználásával három tagú felsorolások készítése megadott feltételek szerint. A válasz feltételezhetően karonként is nagy változatosságot mutathat. A helyzet értékeléséhez továbbá az is hozzátartozik, hogy a mérésnek nem volt magas tétje, az egyetemre már bekerült hallgatók vettek részt a vizsgálatban, legrosszabb esetben is egy kurzus teljesítése forgott kockán. Ebböl kifolyólag egyes esetekben az alacsony feladatkitöltési
Bár a teszteken nyújtott átlagos teljesítmények nem voltak alacsonyak, a szórások és az eloszlások vizsgálata, valamint az itemanalizis eredményei is arra utaltak, hogy a hallgatók egy jelentôs arányának tanulási nehézségei adódhatnak a tanulmányaik során. Az eddigi adatok tükrében nehéz lenne pontos becslést adni erre az arányra. Az egyes feladatok követelményeinek az elemzése képet adott arról, hogy mely tudáselemek, múveletek elvégzése az, amely problémát jelentett a hallgatóknak. További empirikus adatok hiányában csak feltételezések fogalmazhatók meg azzal kapcsolatban, hogy milyen mértékben problematikus egy egyetemi hallgató tanulmányainak eredményességére nézve, ha nehézséget jelent számára a figurális mintázatokban két jellemzó változásában rejló szabályszerúség felismerése, egy négyzetszámokkal növekvó sorozat folytatása, vagy öt elem felhasználásával három tagú felsorolások készitése megadott feltételek szerint. A válasz feltételezhetôen karonként is nagy változatosságot mutathat. 
motiváció is állhat a helytelen megoldások hátterében, ugyanakkor a tanulmányi sikeresség, az egyetemi előremenetel szempontjából ez is ugyanolyan mértékben problémát jelent, mint a képességek nem megfelelő szintje.

Amennyiben elfogadjuk, hogy a feladatok által reprezentált tudás, továbbá a megoldásukhoz szükséges motivációs bázis szükséges feltétele lehet az egyetemi követelmények teljesítésének, akkor munkahipotézisként megfogalmazható, hogy a teszteket kitöltő hallgatók negyede tanulási nehézségekkel nézhet szembe az egyetemi évei alatt. Ezen hallgatók potenciálisan ki vannak téve a lemorzsolódás veszélyének is. Fontos kihangsúlyozni, hogy a vizsgálatban a teljes célcsoport 35\%-a vett részt, a megállapítás tehát elsősorban a mintára vonatkozik, az eredmények általánosítására csak korlátozottan van lehetőség. A hipotézis alátámasztására, a hallgatók tudásának részletesebb feltérképezéséhez tehát további kutatások szükségesek. Egyrészről a kérdés megválaszolásához elengedhetetlen, hogy megvalósuljon a hallgatók nyomon követése, így láthatóvá válik, hogy a jelen teszteken mért tudásnak mekkora az előrejelző ereje. Másrészről árnyaltabb képet nyerhetünk a hallgatók tudásának, motívumainak szerkezetéről, ha a bevezetőben említett többi terület eredménye (szövegértés, matematikai gondolkodás, problémamegoldás, tanulási stratégiák, attitüdök, motívumok) is beemelésre kerül az elemzésekbe.

Az egyetemi tanulmányaikat megkezdő hallgatók gondolkodási képességeinek elemzésén túl a vizsgálat azt is megmutatta, hogy az online adatfelvétel megfelelő infrastruktúra - jelen esetben a könyvtár számítógépparkja - mellett hatékonyan megvalósítható. Az online tesztek kidolgozása és a rendszer működtetése természetesen költségekkel jár, ugyanakkor ezek a ráfordítások hosszabb távon kisebb terhet jelentenek, mintha évről évre kellene a papíralapú méréseket megszervezni. Csak egy példát említve, a kombinatív gondolkodás feladatok manuális javítása önmagában is komoly tehertételt jelentene ilyen nagyságrendủ minták esetében. A technológia elönyeit kiaknázva az adatok hatékony, gyors visszacsatolása is nagymértékben elsősegíthető az érintettek minden szintjén. A hallgatók a teszt befejezését követően azonnali százalékos visszajelzést kaptak, majd az adatfelvétel lezártával az egyéni, személyre szabott visszajelentésben több viszonyítási ponton keresztül is megismerhették erősségeiket, valamint azokat a területeket, ahol fejleszthetik magukat. A mérés megvalósítása már ezen a szinten is jelentős hozzáadott értéket képviselhet, hiszen a hallgatók képet kaphattak saját tudásukról, az eredményeik megismerése kihathat a tanulmányaik optimális tervezésére, lépéseket tehetnek hiányosságaik leküzdéséért. Az eredmények az oktatók számára is haszonnal forgathatók. A kurzusokon részt vevő hallgatók gondolkodási képességszintjeinek ismerete felhasználható a kurzusok tervezéséhez, szükség esetén differenciálásra alkalmas módszerek fejlesztéséhez és hatékony alkalmazásához, valamint az adatok segíthetik a kiemelkedő képességü hallgatók azonosítását is. Az intézményi, kari és egyetemi vezetés átfogó képet kaphat a felvett hallgatók képességeloszlásáról, mely szintén megfelelő inputot szolgáltathat a tervezéshez, például olyan kurzusok is indíthatók, melyek a gondolkodási képességek, a tanulási potenciál fejlesztésére irányulnak.

Összefoglalva, a vizsgálat tapasztalatai és eredményei arra utalnak, hogy a számítógép-alapú mérőeszközök nagy hatékonysággal alkalmazhatóak a felsőfokú tanulmányokat kezdő hallgatók képességeinek objektív, érvényes és megbízható becslésére. Vizsgálatunk empirikus alapot szolgáltat a felsőoktatási expanziót követő új kihívások alátámasztására, hozzájárul a kihívások természetének részletesebb megismeréséhez, valamint a lehetséges megoldások kidolgozásához is. 


\section{Irodalomjegyzék}

Adey, P. \& Csapó, B. (2012). A tudományos gondolkodás fejlesztése és értékelése. In Csapó Benő \& Szabó Gábor (szerk.), Tartalmi keretek a természettudomány diagnosztikus értékeléséhez. Budapest: Nemzeti Tankönyvkiadó. 17-57.

B. Németh, M. (1998). Az iskolai és hasznosítható tudás: természettudományos ismeretek alkalmazása. In Csapó Benő (szerk.), Az iskolai tudás. Budapest: Osiris Kiadó. 115-138.

Carroll, J. B. (1993). Human cognitive abilities: A survey of factor-analytic studies. Cambridge: Cambridge University Press. DOI: 10.1017/CBO9780511571312

Csapó, B. (1988). A kombinativ képesség struktúrája és fejlödése. Budapest: Akadémiai Kiadó.

Csapó, B. (1998). Az új tudás képződésének eszköze: az induktív gondolkodás. In Csapó, B. (szerk.), $A z$ iskolai tudás. Budapest: Osiris Kiadó. 251-280.

Csapó, B. (2001a). A kombinatív képesség fejlődésének elemzése országos reprezentatív felmérés alapján. Magyar Pedagógia, 101(4), 511-530.

Csapó, B. (2001b). Az induktív gondolkodás fejlödésének elemzése országos reprezentatív felmérés alapján. Magyar Pedagógia, 101(3), 373-391.

Csapó, B., Ainley, J., Bennett, R., Latour, T. \& Law, N. (2012). Technological issues of computer-based assessment of $21^{\text {st }}$-century skills. In McGaw, B., Griffin, P. \& Care, E. (szerk.), Assessment and Teaching of $21^{\text {st }}$-century Skills. New York: Springer. 143-230. DOI: 10.1007/978-94-007-2324-5_4

Csapó, B. \& Molnár, Gy. (2017a). Potential for Assessing Dynamic Problem-Solving at the Beginning of Higher Education Studies. Frontiers in Psychology, 8(2022), 1-12. DOI: 10.3389/fpsyg.2017.02022

Csapó, B. \& Molnár, Gy. (2017b). Assessment-based, personalised learning in primary eduction. In Spender, J. C., Gavrilova, T. \& Schiuma, G. (szerk.), Knowledge management in the 21st century: Resilience, creativity and co-creation. Proceedings IFKAD2017. St. Petersburg: St. Petersburg University. 443-449.

Csapó, B. \& Pásztor, A. (2015). A kombinatív képesség fejlődésének mérése online tesztekkel. In Csapó Benő \& Zsolnai Anikó (szerk.), Online diagnosztikus mérések az iskola kezdö szakaszában. Budapest: Oktatáskutató és Fejlesztő Intézet. 367-385.

Demetriou, A., Spanoudis, G. \& Mouyi, A. (2011). Educating the developing mind: Towards an overarching paradigm. Educational Psychology Review, 23(4), 601-663. DOI: 10.1007/s10648-011-9178-3

Derényi, A. \& Temesi, J. (2016, szerk.). A magyar felsőoktatás 1988 és 2014 között. Budapest: Oktatáskutató és Fejlesztő Intézet.
D. Molnár, É. \& Gál, Z. (2019). Egyetemi tanulmányaikat megkezdő hallgatók tanulási mintázata és tanulói profilja. Iskolakultúra, 29(1), 29-41.

Dunbar, K. \& Fugelsang, J. (2005). Scientific thinking and reasoning. In Holyoak, K. J. \& Morrison, R. G. (szerk.), The Cambridge handbook of thinking and reasoning. Cambridge: Cambridge University Press. 705-725.

Európai Bizottság (2010). Európa 2020 - Az intelligens, fenntartható és inkluziv növekedés stratégiája. Brüsszel: Európai Bizottság.

Fishbein, E. \& Grosman, A. (1997). Schemata and intuitions in combinatorial reasoning. Educational Studies in Mathematics, 34, 27-47. DOI: 10.1023/A:1002914202652

Hayes, B. K., Heit, E. \& Swendsen, H. (2010). Inductive reasoning. Wiley interdisciplinary reviews: $\mathrm{Cog}$ nitive science, 1(2), 278-292. DOI: 10.1002/wcs.44

Hódi, Á. \& Tóth, E. (2019). Elsőéves egyetemi hallgatók szövegértés fejlettsége és olvasási attitüdjei. Iskolakultúra, 29(1), 55-67.

Inhelder, B. \& Piaget, J. (1967). A gyermek logikájától az ifjú logikájáig. Budapest: Akadémiai Kiadó.

Johnson-Laird, P. N. (2006). How we reason. New York: Oxford University Press.

Karl Josef Klauer (1997). A tanulás és a kognitíy képességek fejlesztése. Iskolakultúra, 7(12), 85-92.

Klauer, K. J. (1999). Fostering higher order reasoning skills: The case of inductive reasoning. In Hamers, J. H. M., van Luit, J. E. H. \& Csapó, B. (szerk.), Teaching and learning thinking skills. Lisse: Swets és Zeitlinger. 131-156.

Klauer, K. J. \& Phye, G. D. (2008). Inductive reasoning: A training approach. Review of Educational Research, 78(1), 85-123. DOI: 10.3102/0034654307313402

Molnár, G. (2019). Nőtt az egyetemi tanulmányaikat kezdő diákok tanulási potenciálja és problémamegoldó képessége: években mérhető különbségek a diákok között. Iskolakultúra, 29(1) 3-16.

Molnár, G. \& Csapó, B (megjelenés alatt). A felsőoktatási tanulmányi alkalmasság értékelésére kidolgozott rendszer a Szegedi Tudományegyetemen: elméleti keretek és mérési eredmények. Educatio, benyújtott kézirat.

Molnár, G., Greiff, S. \& Csapó, B. (2013). Inductive reasoning, domain specific and complex problem solving: relations and development. Thinking skills and Creativity, 9(8), 35-45. DOI: 10.1016/j. tsc.2013.03.002

Molnár, G., Makay, G. \& Ancsin, G. (2018). Feladatés tesztszerkesztés az eDia rendszerben. Szeged: SZTE Oktatáselméleti Kutatócsoport. 
Nagy, L.-né (2006). Az analógiás gondolkodás fejlesztése. Budapest: Müszaki Könyvkiadó.

Pásztor, A. (2016). Az induktív gondolkodás technológia alapú mérése és fejlesztése. PhD-értekezés. SZTE BTK Neveléstudományi Doktori Iskola, Szeged. DOI: 10.14232/phd.3191

Pásztor, A., Molnár, Gy., Korom, E., B. Németh, M. \& Csapó, B. (2017). Online assessment of inductive reasoning and its predictive power on inquiry skills in science. Paper presented in the 17th EARLI Conference. Tampere, Finland, 509.

Poddiakov, A. N. (2011). Multivariable Objects for Stimulation of Young Children's Combinatorial Experimentation and Causal-Experimental Thought. Psychology in Russia: State of the Art, 4, 397-420. DOI: 10.11621/pir.2011.0027

Resing, W. C. M. (1993). Measuring inductive reasoning skills: The construction of a learning potential test. In Hammers, J. H. M., Sijstma, K. \& Ruijssenaars, A. J. J. M. (szerk.), Learning potential assessment.
Theoretical, methodological and practical issues. Amsterdam: Swets and Zeitlinger. 219-242.

Simon, H. A. \& Lea, G. (1974). Problem solving and rule induction: A unified view. In Gregg, L. W. (szerk.), Knowledge and cognition. Hillsdale: NJ: Erlbaum.

Simonton, D. K. (2010). Creative thought as blindvariation and selective-retention: Combinatorial models of exceptional creativity. Physics of life reviews, 7(2), 156-179. DOI: 10.1016/j.plrev.2010.02.002

Wu, H. \& Molnár, Gy. (2018). Interactive problem solving: Assessment and relations to combinatorial and inductive reasoning. Journal of Psychological and Educational Research, 26(1), 90-105.

Zlatkin-Troitschanskaia O., Shavelson R. J. \& Kuhn C. (2015). The international state of research on measurement of competency in higher education. Studies in Higher Education, (40), 393-411. DOI: 10.1080/03075079.2015.1004241

\title{
Köszönetnyilvánítás
}

A felsőoktatási tanulmányi alkalmasság értékelésére kidolgozott rendszer fejlesztését és müködtetését az EFOP-3.4.3-16-2016-00014 A Szegedi Tudományegyetem oktatási és szolgáltatási teljesitményének innovatív fejlesztése a munkaerö-piaci és a nemzetközi verseny kihívásaira való felkészülés jegyében címü projekt támogatja.

\begin{abstract}
Absztrakt
A felsőoktatás expanziója számos új kihívás elé állítja az oktatási rendszereket, többek között a hallgatók tudásában, képességeiben és motivációiban jelentkező megnövekedett variancia kezelése elé. Megfelelő intervenció híján a gyengébb képességű hallgatók diplomaszerzése elhúzódhat vagy lemorzsolódhatnak, a jobb képességü hallgatók azonosítása is nehezebbé válik, a hatások összegződésével jelentősen romolhat a felsőfokú képzések eredményessége. Az új kihívásokra való hatékony reagálás minden szinten összetett feladat, ugyanakkor a tervezéshez és a beavatkozások megvalósításhoz is nagymértékben hozzájárulhat, ha képet kapunk a tanulmányaikat megkezdő hallgatók általános gondolkodási képességeinek fejlettségéről. A kutatás célja a Szegedi Tudományegyetemen tanulmányaikat kezdő hallgatók induktív és kombinatív gondolkodásának online vizsgálata. Az adatfelvételben 1682 fö vett részt. Az induktív gondolkodás tesztben figurális sorozatok és analógiák, valamint számsorozatok és számanalógiák szerepeltek. A kombinatív gondolkodást mérő feladatotokban képekből, valamint betűkből és számokból kellett különböző összeállításokat megadni. Az adatfelvétel az eDia rendszer alkalmazásával valósult meg az egyetem könyvtárának számítógépparkjában, a kitöltést mérési koordinátorok felügyelték. Bár a teszteken nyújtott átlagos teljesítmények nem voltak alacsonyak, a szórások és az eloszlások vizsgálata, valamint az itemanalízis eredményei alapján feltételezhető, hogy a teszteket kitöltő hallgatók negyede tanulási nehézségekkel nézhet szembe az egyetemi évei alatt. Vizsgálatunk hozzájárul a felsőoktatási expanziót követő új kihívások természetének részletesebb megismeréséhez, valamint a lehetséges megoldások kidolgozásához is.
\end{abstract}

